Historic, Archive Document

Do not assume content reflects current scientific knowledge, policies, or practices. 

\&

1.

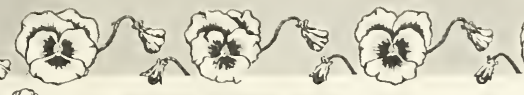

(2) in

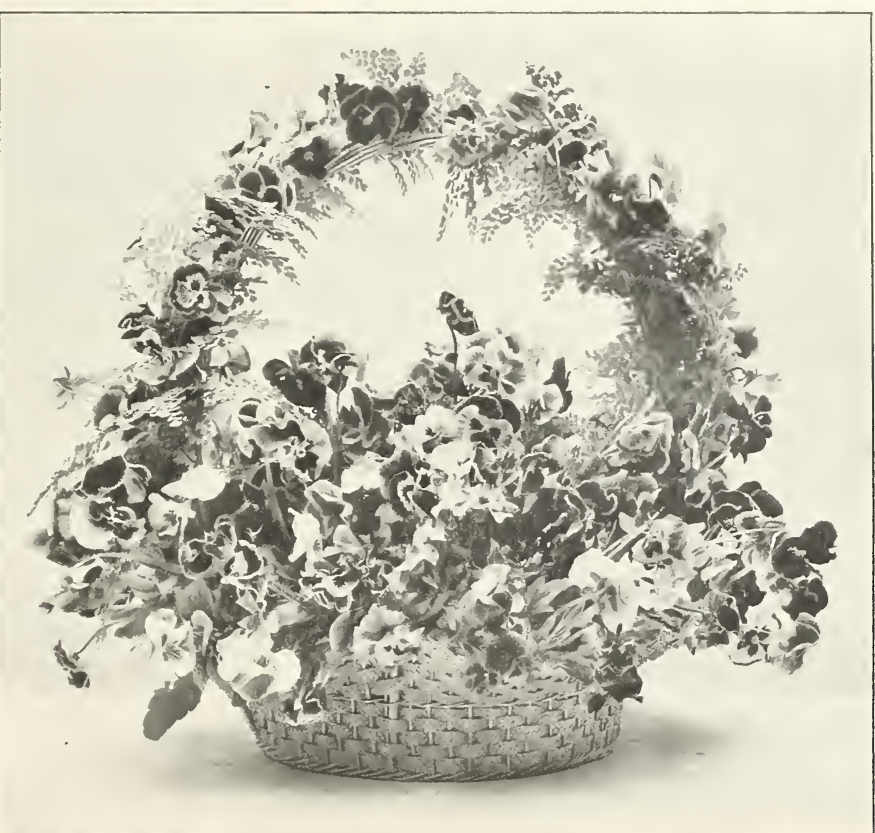

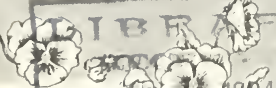
, the civ

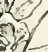

(4) $(1)$

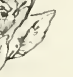
.

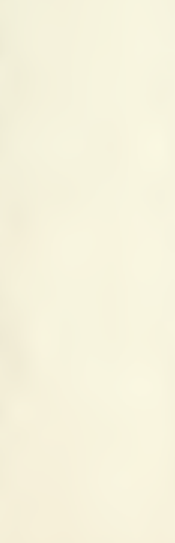

.

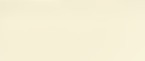

WHOLESALE ONLY

\section{Steele's Pansy Gardens} Originators of Mastodon Pansies

\section{Cable Address: "Pansy"}

Since 1893

East 44th and Powell Streets

Portland, Oregon, U. S. A.

\section{Season of 1921}

Mastodon Pansies, huge in size, marvelons in form and substance, with a range of colors including those of the world's best growers as well as many new and unique shades originaterl by us and not to be found in any other strain represent the result of many years of study and application of the best method of plant breeding and to the special and exclusive cultivation of pansies. Mastodon Pansies have won the praise and patronage of many of the foremost authorities on floriculture in America, and when better pansies are grown they will be improved Mastodon Pansies.

Twenty-eight years of exclusive cultivation of pansies, and the largest growers of pansy seed and plants only in the world.
E. J. Steele, Manager

M. I. Steele, Secretary

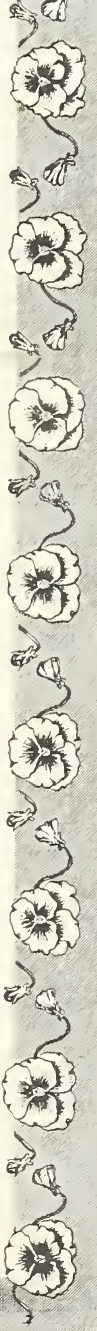




\section{STEELE'S PANSY GARDENS, PORTLAND, OREGON, U. S. A. Wholesale Only}

\section{HOW DID IT HAPPEN? READ OUR CREED}

We believe that the highest degree of perfection can be attained only by an exclusive specialist.

We believe that a definite aim and purpose must be backed by untiring industry.

We believe in "delivering the goods" of the quality we advertise, and in good measure thereof.

We believe that in serving promptly the best interests of our patrons we cannot avoid being successful ourselves.

We believe in any possible controversy that may arise, that our customer is right.

\section{IF YOU ARE WITH US}

in our view of what a business policy should be, send us an order, and we will show you how it works.

\section{MASTODON PANSIES}

The strain originated by us and named Mastodon, includes white, dark center, dark blue center and light blue center, pure white, black, Burgundy red, lavender, violet, light blue, bronze, royal purple, rose, cerise red, red with silver rim, mahogany, yellow, wine colored, red and gold. lavender and gold, tango red, new, some ruffled types, with a dozen or more variations in each color, in size measuring up to three and seven-eighths inches in diameter.

\section{SEEDLINGS TO THE TRADE}

\section{Season of 1921-22}

Regular price, large size, Mastodon Mixed Private Stock, per 500, \$3.00; per 1000, \$5.50; per 2500, \$12.50; per 5000, \$24.50; per 10,000, \$48.00.

For Greenhouse Special mixed add $\$ 1.00$ per 1000 to above prices. Crop ready Sept. 10. After Nov. 10, add $10 \%$ to above prices.

\section{METHODS OF PACKING}

Except for very short distances all shipments are packed in moss. All of our boxes are specially made to fit shipments, and are of the lightest made, and exactly as we would have them if we paid the charges ourselves. Terms C. W. O.

See shipping conditions below. All prices f. o. b. Portland. Those who wish plants PREPAID may add $\$ 2.00$ per 1000 , or for less than 1000 , for prepay charges. Excess charges refunded in plants or cash as requested.

All orders accepted subject to growing conditions, market changes, and any and all conditions beyond our control.

\section{Shipping Conditions}

Owing to the great distances we are obliged to cover in shipping seedlings during the early Fall season, often encountering tropical degrees of Summer heat, we have been taught by costly experience that some restriction is necessary in filling orders for seedlings. Therefore, before ordering, kindly note points beyond which we cannot ship during early, Fall season:

1. After Sept. 10 seedlings will be billed to points 800 miles or less from this city.

2. After Oct. 1 seedlings will be billed to San Diego, Calif., and all way points, and east to Omaha and all way points.

3. After Oct. 15 seedlings will be shipped anywhere west of Mississippi. All offers made subject to stock being unsold. 


\section{STEELE'S PANSY GARDENS, PORTLAND, OREGON, U. S. A. Wholesale Only}

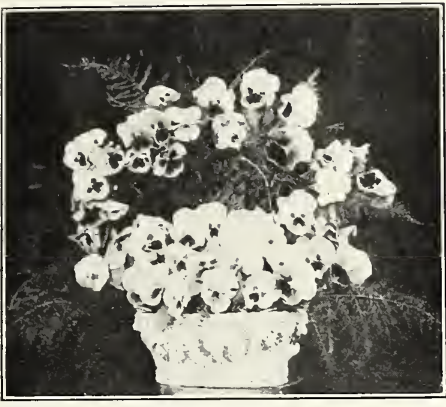

MASTODON PANSIES

\section{PREPARING BED FOR RESETTING PLANTS}

Too much cultivation and preparation of the soil before making your beds for seedlings or re-set plants is impossible. Too little cultivation and preparation is common and almost fatal to any degree of success. Excellent drainage is essential. For re-sets the soil should be broken up to a depth of ten to twelve inches and thoroughly pulverized to a depth of six to eight inches. The ground should be clean and free of all trash and weeds. If soil is deficient in humus, mix in about two inches of well rotted manure.

For re-set plants make your beds four to five feet wide, and line them up so that the paths between the beds will afford drainage. In a rainy climate it's a good plan to raise your beds by making your paths deep. Cover beds with a mulching of dairy yard or stock yard scrapings, or any well rotted, pulverized manure to a depth of about $1 \mathrm{I} / 2$ inches. Set your seedlings deeply, and in rows across the bed seven to eight inches apart, so that you can use the hoe. For marketing purposes set plants $2 \frac{1}{2}$ to 3 inches apart in the row. For display beds double space in the row.

\section{PREPARING BED FOR GERMINATING SEED}

If your soil is not of the quality of first-class potting soil prepare your bed for sowing as follows:

1. Have your ground perfectly clean and free of weeds and trash, pulverized to a depth of six or more inches.

2. On the level surface spread evenly a layer of pulverized manure, barnyard scrapings preferred, to a depth of at least one inch.

3. Overlay manure with half inch of the best soil you have, thoroughly pulverized.

4. Roll or rake down and tamp surface true and smooth.

5. Use the hose freely and soak down the bed several inches.

6. Sow your seed in drills or broadcast-we sow broadcast.

7. Cover as lightly as possible with your best soil or sand. Sand is best.

8. Use spray of water to moisten surface.

9. Allowing plenty of ventilation, keep your beds moist, quite moist, but not soaking wet, until plants come up.

We use unbleached sheeting, cheapest grade, to retain moisture. As soon as plants begin to come through freely we remove sheeting permanently, and sift tops of beds with thin layer of barnyard scrapings.

Never allow your beds to become dry. Any dryness after seeds sprout is absolutely fatal. These directions are for sowing in the open field, but will apply when using flats or cold frames. We use 60 to 75 square feet to sow an ounce of seed.

If possible, alternate your pansy crop with some other crop.

With labor, other expense and space occupied to be considered, there is no crop grown that will pay the handsome profit of a bed of pansy seedlings or blooming plants.

After a careful study of various methods employed in growing pansy seed in this and other countries, I am convinced that Mastodon Pansies withstand the rigors of a northern winter better than any other strain known to us. Why? Write us.

THE UNUSUALLY HIGH GERMINATING QUALITIES OF MASTODON PANSY SEED is a revelation to all extensive growers who use our seed.

\section{THE SEED}

The growing of Mastodon Pansy seed is a branch of our business that is given my personal attention daily, from the time the plants are selected in bloom to the time when the seed is sealed in the package, so that I know positively the premier quality of every package, and you get exactly the same seed that I sow and grow.

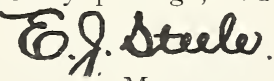

Manager. 


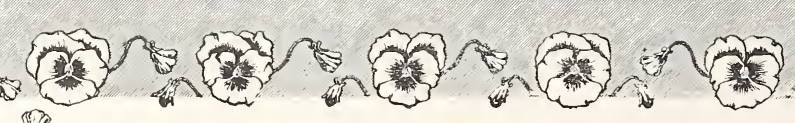

\section{(1)}

(1)

s.tuly

STEELE'S PANS

Wholesale Only

"Pansy"

.

N(s)

,

a

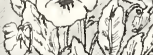

Ev

aivers

FOR DESCRIPTION OF MASTODON PANSIES SEE PAGE TWO

(r)

No seed packets containing less than 1/16 oz. are offered except Vulcano; 2

oz. Greenhouse Special Mixed and $2 \mathrm{oz}$. Private Stock Mixed at $4 \mathrm{oz}$. rate.

PRICES NET

Steele's Mastodon Greenhouse Special, Nixed

$1 / 16 \mathrm{oz} .1 / 8 \mathrm{oz} . \quad \mathrm{T} / 4 \mathrm{oz} . \mathrm{T} / 2 \mathrm{oz} .1 \mathrm{oz} . \quad 3 \mathrm{oz} . \quad 4 \mathrm{oz}$.

O. K. outside.................\$ \$0.65

Steele's Mastodon Private Stock, Mixed....... .65

$\$ 1.00 \quad \$ 1.75 \quad \$ 3.25 \quad \$ 6.00 \$ 16.50 \$ 22.00$

$\begin{array}{lllllll}65 & .75 & 1.50 & 2.75 & 5.00 & 14.00 & 18.00\end{array}$

Steele's Mastodon Greenhouse Special-New:

A wonderful collection of rich, velvety

shades, many light colors, in great variety

and huge in size, with fine long stems, and containing all our newest and finest types. We cannot recommend these too highly for outside or inside cultivation.

5

The price of each of three varieties named below is as follows: $1 / 16 \mathrm{oz}, \$ 1.00$.

Steele's Mastodon Striata-Our Novelty. Of great size and varied types, mostly dark and rose pink shades, mottled and beautifully striped in true sunburst fashion. A genuine sensation among fine pansies.

Mile. Irene-New. A shade never before known to pansies. A tango red, and in every other respect a grand flower with a long. strong stem.

Steele's Mille. Isabelle-Our novelty. A ruffled bronze, a few are yellow. Huge in size and a sensation in the pansy world.

Improved Vulcano, New-A rich, velvety Burgundy red of immense size that will cause a sensation even in the company of Mastodon Pansies. Price, 400 seeds, 50c.

The prices of each of the twelve varieties named below are same as Greenhouse Special Mixed.

Steele's Mastodon Madame Steele-Elk's purple.

Steele's Mieteor-IVine red; a profuse bloomer.

Steele's Improved Beaconsfield-New. A fine bluish purple with a distinct lavender tinge on the upper part of the upper petals. A beautiful European variety, but having the size of the true Mastodon type.

Steele's Black Mastodon-Nearly all jet black; a few very dark purple and all velvety in substance and of immense size.

Steele's Bronze Mastodon-V'Tery large. All the different shades from burnished brass to gold: wonderfully tinged with nearly every color known to pansies.

Steele's Panama Pacific-A huge deep yellow ; some with dark centers, some without.

Steele's Prince Henry-A splendid dark blue of immense size.

Steele's Madame Perrett-A beautiful and distinct type with edges of petals frilled-bordered white; colors dark wine, pink and red.

Steele's Parisian Yellow-A pure yellow of the grandest, form and size.

Steele's Grand Duke Michel (Improved Candidissima)-The finest and largest all-white pansy in the world.

Steele's White Mastodon (dark center) - The largest pansies we have ever seen.

Steele's Mastodon Adonis-New; of huge size; light blue, baby blue and lavender shades.
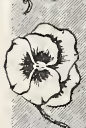